\title{
LAURENCE BEDFORD POTTER: PIONEER ORNITHOLOGIST OF SOUTHWESTERN SASKATCHEWAN
}

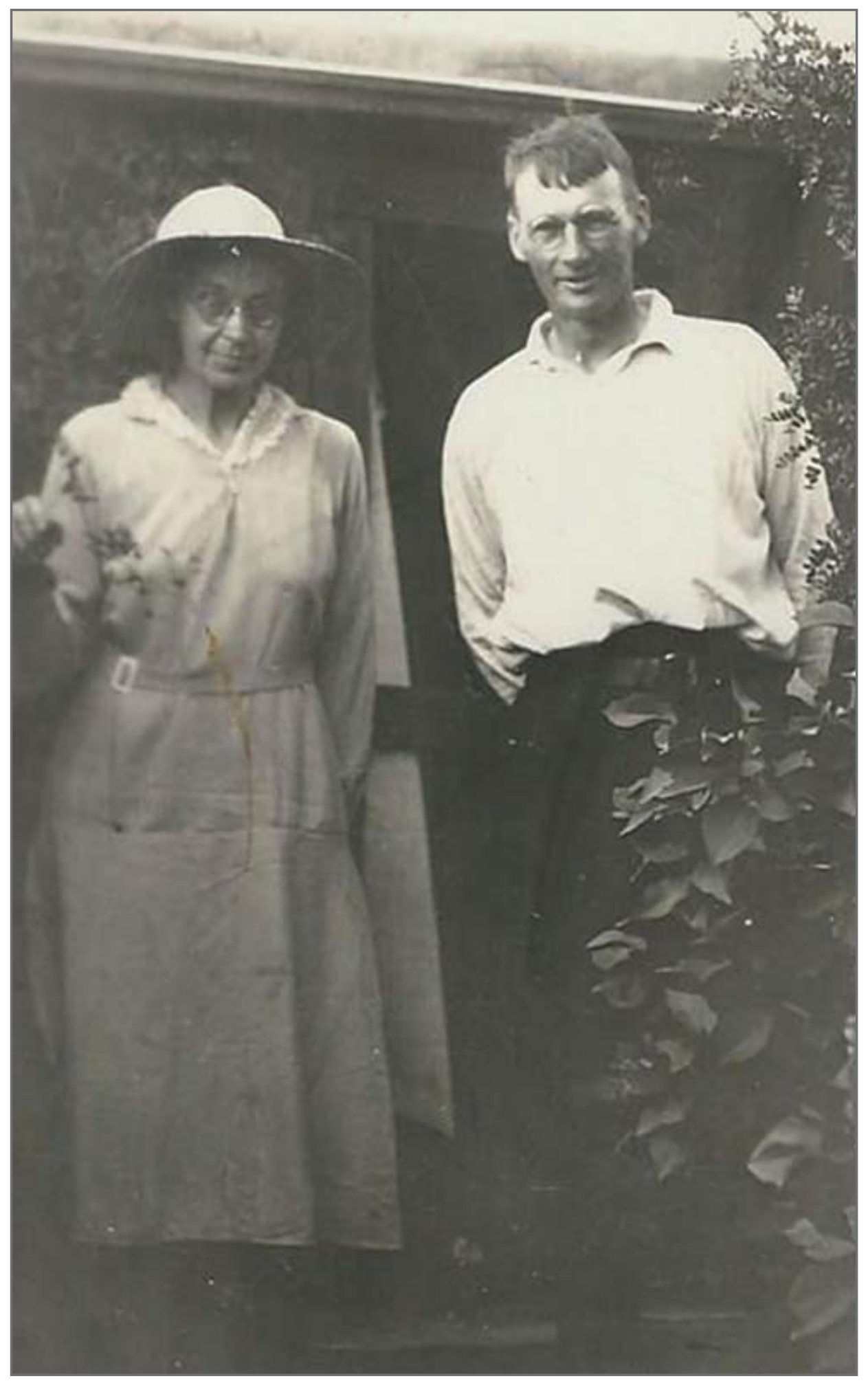

Isabel \& Laurence Potter on Sunday, July 17, 1932 at their Gower Ranchhouse back door, up-river from Eastend, SK. Photo courtesy of the Eastend Historical Museum.
Julia Adamson

210 Appleby Court

Saskatoon, SK S7M 4B2

djadamson@sasktel.net

Laurence Bedford Potter

(November 4, 1883 - November

$6,1943)$ was one of the first and

most respected Saskatchewan

ornithologists - "one of our few

reliable bird observers" (Houston). ${ }^{5} \mathrm{~A}$ cattle rancher and resident at Gower Ranch, Eastend, Saskatchewan,

Potter was born in Monmouth, Great Britain, emigrating to the NorthWest Territories, Canada in 1901. Having lived a life close to nature, he loved the birds, beasts, and flowers, and intimately sensed his world around him. He knew every portion and parcel of his Gower Ranch like the back of his hand. Oh! To have had the opportunity to be guided by Potter from nest to nest, to awaken every morning with gladness looking out on nature, birds, and relishing the health-giving air around us!

Potter first sent bird arrival dates each spring to the Territorial Natural History Society, published by the Department of Agriculture in Regina until 1909 (Willing 1902,17 Belcher 1996'), and later to the U.S. Biological Survey in Washington until 1940 (Houston pers. comm.). Potter published nine Christmas Bird Counts, ${ }^{6}$ as well as 19 notes and articles in Condor, eight in Canadian Field-Naturalist, one in Auk and one in Blue Jay (Houston and Houston 1979, ${ }^{7}$ Godfrey 1950, ${ }^{4}$ Potter 1942)..$^{10}$ J. Dewey Soper $(1944)^{15}$ described Potter: "In 1906, he 
began to methodically write up his observations on the local avi-fauna, a habit which he continued faithfully thereafter. His journals are replete with interest and occupy a unique place in the annals of Saskatchewan ornithology ... he gradually gained distinction as an authority on the birds of southwestern Saskatchewan where he established many notable 'firsts' for the provincial bird list."

Potter's 'firsts' for Saskatchewan included the Screech Owl in 1904 (sight record at close range), Poorwill in 1905, Townsend's Solitaire in 1908, Pinyon Jay in 1910 (sight record only), Yellow-breasted Chat in 1922 (with first nest the same year), Gray-crowned Rosy Finch, Lark Sparrow and Rufous Hummingbird in 1932 (final three new species during one of the driest years on record). Potter had two first Saskatchewan nesting records, that of a Whitecrowned Sparrow in a gooseberry bush in 1919 and the first Bullock's Oriole nest on July 10,1937 . In 1922, Potter had the farthest-west nesting of the Eastern Bluebird (Smith, Houston and Roy 2019). ${ }^{13}$

Three fellow rancher naturalists in southwestern Saskatchewan were Charles Frederick Holmes south of Dollard (Houston 2012) who collected the first three Saskatchewan specimens of the Sage Thrasher and found the first nest of the Yellow-breasted Chat (Godfrey 1950), ${ }^{4}$ Spencer Pearse at Ravenscrag, and Steve Mann at Skull Creek post office (Belcher 1969). ${ }^{2}$ Steve Mann was the only one of the four born in the Cypress Hills. He led spring field excursions to the Cypress Hills several times and became president of the Saskatchewan Natural History Society, 1962-1964. He also sighted the first Mountain Chickadee in Saskatchewan, present at his feeder from November 30, 1966 to April 22, 1967 (Belcher
1969). ${ }^{2}$

When Potter died, Holmes wrote to Mann of "the passing of a friend of thirty-five years and one of his calibre and irreplaceable. I shall miss him terribly for neither ever saw a new bird without going into a huddle over it. It was not that I saw very much of him, but one knew that he was always there." (Houston, 1979). ${ }^{7}$

Laurence Bedford Potter was born November 4, 1883 at St. Thomas Vicarage, Monmouth, the ninth child in a family of 12 . His father, Peter Potter III B.A., M.A. (1841-1914), was the Vicar of St. Thomas. Potter came from an English family of distinction. Peter Potter I (d 1843), the chief land agent to Lord Bradford of Gorway House was the great-grandfather of Laurence Bedford Potter. Peter Potter I assumed duties for collecting rents, handling sales, and disputes for the Earl of Bradford who was the Lord of the Manor of Walsall — nearly the entire parish. In 1828, Lord Bradford built a villa at Wood End named Gorway House in Walsall, Stafford, England for Peter Potter I and his family of five girls and three sons. Reverend Potter III, who was very much admired in the community, often bicycled to see the birds, trees, and garden along the countryside (Soper, 1944). ${ }^{15}$

Potter was a self-taught naturalist and a pioneer writer of articles about birds. Potter could find no one around to answer his questions about the birds when he arrived in Saskatchewan from England in June 1901 (age 18) and began his life-long habit of observing the birds around him in his personal journals. His field trips covered especially the southeast corner of the Cypress Hills and the Frenchman River valley, as reported in his unpublished diaries. He accumulated a substantial library of books. Respected for his field experience, he sent occasional rare specimens to the Provincial Museum of Saskatchewan (Regina), the Grand Coteau Museum (Shaunavon) and The National Museum (Ottawa). Readers of the 10-years-in-writing Birds of Saskatchewan (Smith, Houston and Roy, 2019) ${ }^{13}$ will this coming winter be surprised to read how much Potter contributed.

Potter and his sister Mary Isabella Potter (Isabel) (1871-1949) joined their elder brother Ernest Stileman Potter (1874-1956), who was ranching near Eastend along the Frenchman River valley. Ernest arrived near Eastend in 1894 at age 20. Their sister, Olive Spilsbury Potter (1882-1935), came to visit for two years between 1903 and 1905 .

Considering the wide open plains of 1901 and the sparse settlements, Potter was very active in the naturalist community. In 1921 Mr. Percy Taverner came from the National Museum in Ottawa to southwest Saskatchewan and spent days together with Potter. Potter was both host and guide for other professional naturalists $\mathrm{H}$. Hedley Mitchell, Fred Bradshaw, Fred G. Bard, and J. Dewey Soper. Potter wrote articles beginning around 1921 for Condor, Auk and Canadian Field-Naturalist and contributed bird counts to Bird-Lore before its name change to Audubon Field Notes. Potter travelled in October 1926 to the first AOU meeting held outside the United States - in Ottawa and participated in the group photo of 48 attendees (Cranmer-Byng 1996). Potter published a summary of important bird observations in volume 1 of Blue Jay, 1942-43. ${ }^{10}$

Donald $\mathrm{G}$. Wetherell noted that as there was "a growing public demand and interest during the interwar years, several publications began to run an increasing number of nonfiction articles and features about 


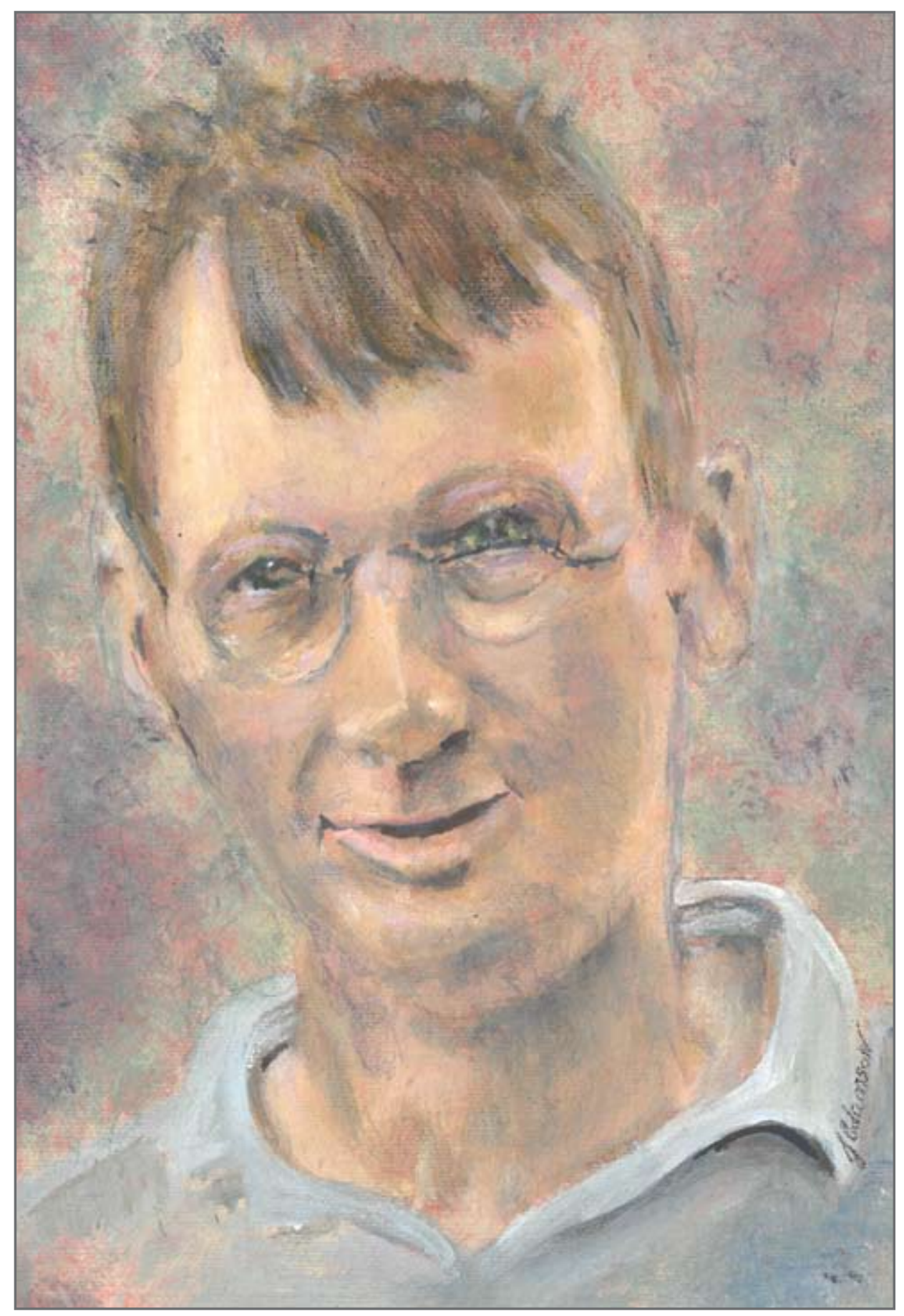

Adamson, Julia. Laurence Potter (Painting). Photo reference courtesy of Eastend Historical Museum.

wildlife and natural history. Some examples include contributions by Laurence Potter, a bird enthusiast at East End in southwest Saskatchewan who provided notes on birds to Ernest Ingersoll, an American naturalist, [who] wrote a weekly column for a Montreal newspaper, The Family Herald and Weekly Star, in the 1920s" (Wetherell, 2016). ${ }^{16}$ During this era, a half million readers in bird populations as settlement, agriculture and ranching extended their reach into the native grasslands of the southwestern prairies (Potter, 1930). ${ }^{9}$

On June 13, 1944, southwest stockmen were told that cattle numbers had already reached the capacity of the rangeland. In the Regina Leader-Post, Dr. S.E. Clark of the Swift Current Experimental Station reported that there were about 100,000 head of cattle in Canada, that pasture lands were reaching or even exceeding their full grazing capacity, and that ranchers should consider culling those herds, rather than expanding.

Besides his natural love for birds, Potter explored horticulture by planting crab apples, plums, cherries, raspberries, gooseberries, and currants. His specialties were the native red, amber, and yellow Ribes also known as the Missouri flowering currant. The Morden Experimental Farm lists 10 new varieties of wild currants in the "L.B. Collection." The Arnold Arboretum, Harvard University, also received eight varieties.

Mary Isabella Potter, the eldest of the family came to Canada in 1901 (age 30), and returned to England after Laurence Potter died of cancer in 1943 at Eastend. The past 10 years or so of his life had been in poor health, and he sought surgical operations across Canada and the United States to no avail. According to Houston, Potter was admitted to the Grey Nuns Hospital in Regina between May 18 and 26, 1943. At this time, Potter had made arrangements to sell Gower Ranch to Reuben Stredwick of Eastend. Potter returned for surgery on bowel cancer June 11, 1943. Recovering, he spent a few months living with Isabel in Eastend. Just before passing away, Potter had an enjoyable supper with 
naturalist J. Dewey Soper, a widely traveled Canadian ornithologist, explorer, zoologist, prolific author and the Migratory Bird Officer out of the National Museum, Ottawa. Soper wrote of Potter, "The Canadian West has lost not only one of its prominent pioneers, but also one of its best field ornithologists" (Soper, 1944). ${ }^{15}$ Potter passed away November 5, 1943, one day following his 60th birthday; his ashes were taken to England. His sister Isabel died in England on July 20, 1949 at the age of 78 .

For further information about Potter, his family history and to delve into ornithology journal articles written by Laurence Potter, please contact the Eastend Historical Museum and Cultural Centre, 306 Red Coat Drive, Eastend, SK. There, Bryson LaBoissiere has taken the lead on preserving and commemorating the legacy of Laurence Bedford Potter.

\section{Acknowledgements:}

I must express my profound gratitude to Stuart Houston for his invaluable participation and input. I could not have imagined having a better advisor for the development of this research work into the ornithological life of Laurence Potter.

\section{References}

1. Belcher M (1996) The Isabel Priestly Legacy: Saskatchewan Natural History Society, 1949-1990. Special Publ. SNHS No. 19.

2. Belcher M (1969) Steve Mann, ranchernaturalist of Skull Creek, 1895-1968. Blue Jay 27:122-128.

3. Cranmer-Byng JL (1996) A life with birds: Percy A. Taverner, Canadian ornithologist, 1875-1947. Canadian Field-Naturalist 110:1-254. Group photo of 48 attending the AOU meeting, Ottawa.

4. Godfrey WE (1950) Birds of the Cypress Hills and Flotten lake regions, Saskatchewan. Bull. 120, Biological series 40, National Museum of Canada.

\section{POETRY}

\section{A CHANGING OF THE GUARD}

Spent autumn's forces, slow, retreating, bed

down for the night--not uniformed in reds

and blazing yellows, but dun-clothed in tans,

sere-brown, and dirty russet. Winter's slow

advance, mere flake by slow-descending flake,

soon covers all, creates a world of white,

with soft-blue shadowing, and later mounds

of morning diamonds or yellow glazing.

\section{Victor C. Friesen}

P.O. Box 65

Rosthern, SK SOK 3RO

victorcfriesen@yahoo.com

5. Houston CS (2012) A biographical sketch of prairie naturalist Charles F. Holmes, 1888-1948. Saskatchewan History 64(1):24-31 .

6. Houston CS, Houston, MI (1976) Prairie Christmas Bird Counts, 1906-1941. Blue Jay 34:214-219.

7. Houston CS, Houston, MI (1979) Four Rancher Naturalists of the Cypress Hills Saskatchewan. Blue Jay 37:9-19.

8. Mitchell HH (1919) Bird notes from Saskatchewan. Condor 21:222-225.

9. Potter LB (1930) Bird life changes in twenty-five years in southwestern Saskatchewan. Canadian Field-Naturalist 44:147-149.

10. Potter LB (1943) Saskatchewan bird records made since the publication of Mitchell's catalogue of Saskatchewan birds in 1924. Blue Jay 1(3:25).

11. Provincial Archives of Saskatchewan. Saskatchewan Historical Society. Collection Call Number SHS50. Description of Item LB Potter 1908-1950 referenced from Archives SAFA guide S44.

12. Sieglinger J Beardsley (1928). Broomcorn Experiments at the United States Dryland Field Station, Woodward, Okla. Issue 51 of Technical bulletin (United States. Department of Agriculture). U.S. Department of Agriculture. p. 15.

13. Smith AR, Houston CS, Roy JF (2019). Birds of Saskatchewan. Regina: Nature Saskatchewan. 816 pp.

14. Soper JD (1942). The Long-tailed Chat in Saskatchewan. Canadian Field-Naturalist 54:116.

15. Soper JD (1944). Laurence Bedford Potter, 1883-1943. Canadian FieldNaturalist 58:66-67.

16. Wetherell DG (2016). Wildlife, Land, and People: A Century of Change in Prairie Canada. Carleton library series 238. McGill-Queen's University Press, p. 607.

17. Willing TN (1902) Territorial Natural History Society, Appendix D in Provincial Archives of Saskatchewan, 1903, p. 197.

\section{External Sources}

Saskatchewan Historical Society. SK Archives Call Number SHS121 Description of Item Ranching Clippings File 1838-1945. 